九州大学学術情報リポジトリ

Kyushu University Institutional Repository

\title{
Estimation of Daily Cyclic Water Quality in the Shikinawa Lake
}

Tuan, Nguyen Van

Graduate School of Bioresource and Bioenvironmental Sciences, Kyushu University

Cong, Vu Chi

Faculty of Agriculture, Kyushu University

Hamagami, Kunihiko

Faculty of Agriculture, Kyushu University

Haraguchi, Tomokazu

Faculty of Agriculture, Kyushu University

他

https://doi.org/10.5109/10099

出版情報：九州大学大学院農学研究院紀要. 53 (1)，pp. 241-249，2008-02-28. Faculty of Agriculture, Kyushu University

バージョン :

権利関係 : 


\title{
Estimation of Daily Cyclic Water Quality in the Shikinawa Lake
}

\author{
Nguyen Van TUAN ${ }^{1}$, Vu Chi CONG, Kunihiko HAMAGAMI, \\ Tomokazu HARAGUCHI*, Ken MORI** \\ and Yasumaru HIRAI
}

\author{
Laboratory of Bioproduction and Environment Information Sciences, Division of Bioproduction and \\ Environment Information Sciences, Department of Bioproduction and Environmental Science, \\ Faculty of Agriculture, Kyushu University, Fukuoka 812-8581, Japan \\ (Received November 9, 2007 and accepted November 30, 2007)
}

\begin{abstract}
Water quality is one of the main characteristics of water storage reservoirs or lakes. A water quality profile, in both of spatial and temporal variations, plays a very important role in assessment and management of lake water quality. In order to have deeply understanding of the lake water quality parameters, some observation plans were decided for the Shikinawa Lake, in different climate conditions including summer, typhoon occurring time, end of autumn, and before spring. Results of the first observation, which have done in summer, are presented and discussed in this paper. Some important properties of water quality situation of the Shikinawa Lake were obtained and analyzed. Measured data also gave a clearly understanding of relationship among water quality parameters, effects of climate condition and aquatic plant coverage on lake water quality distribution. Besides, periods of activities of convection term and wind induction on water quality were cleared from analyzed data. In further studies, these data will be used as important part of three-dimensional model for lake water quality.
\end{abstract}

\section{INTRODUCTION}

Beside rivers and streams, lakes or reservoirs are main fresh water sources for life. The quality of this fresh water is vitally important. We depend on surface and groundwater sources for our drinking water. We also need water to grow crops, to harvest fish, to run machinery, to generate energy, to carry wastes, to enhance the landscape and for a great deal more. We use water for washing and cleaning, industrial abstraction, recreation, cooking, gardening and fishing, as well as simply to enjoy it. These water sources also support a large variety of wildlife and they are part of our natural scenic heritage.

Assessment of water quality is necessary to determine the health of a lake and its suitability for public uses. Lake water quality assessment provides lake water quality criteria, which can improve how we manage our lake resources and how we measure current conditions. It also provides a knowledge base that we can use to protect and restore our lakes. A lake water quality monitoring is necessary to gain insight into characteristics of lake's water quality as well as the fate of constituent in the water bodies.

From those purposes, the Shikinawa Lake in Kasuya machi, Fukuoka prefecture was chosen to study in an effort to find some primary properties of water quality.

\footnotetext{
1 Laboratory of Bioproduction and Environmental Information Sciences, Division of Bioproduction and Environment Sciences, Department of Bioproduction Environmental Sciences, Graduate School of Bioresource and Bioenvironmental Sciences, Kyushu University

* Associate Professor, Faculty of Agriculture, Saga University, Japan

** Corresponding author (E-mail: moriken@bpes.kyushu-u.ac.
} jp)
Important characteristics and relationship or interaction between water quality and meteorological data, and water quality parameters among themselves were pointed out and presented in this paper.

\section{MATERIALS AND METHODOLOGIES}

\section{Study area: the Shikinawa Lake}

The Shikinawa Lake is located in Kasuya Machi, a small city in the east area of Fukuoka prefecture (see Fig. 1). Water from this lake is used for agricultural irrigation. Some main characteristics of Shikinawa Lake are shown in Table 1. Based on lake classification standards, this is a small and shallow lake.

Table 1. Main characteristics of the Shikinawa Lake

\begin{tabular}{lcr}
\hline \multicolumn{1}{c}{ Characteristic } & Unit & Value \\
\hline Basin area & ha & 25.8 \\
Water surface area & ha & 4.93 \\
Total volume & $\mathrm{m}^{3}$ & 123,000 \\
Effective volume & $\mathrm{m}^{3}$ & 123,000 \\
Maximum depth & $\mathrm{m}$ & 5.0 \\
Average depth & $\mathrm{m}$ & 2.5 \\
Maximum length & $\mathrm{m}$ & 350 \\
Maximum width & $\mathrm{m}$ & 175 \\
\hline
\end{tabular}

\section{Data collection}

Field observation was performed in two days, $7^{\text {th }}$ and $8^{\text {th }}$ August, 2007 at the Shikinawa Lake. In order to find out effects of aquatic plants cover on variation of water quality parameters, five measuring stations were set at the south-west side of the lake (see Fig. 1). Station S1 was set near to center of the lake, station S3 was located at the middle of water surface area where covered by aquatic plant, station S2 was defined at the boundary of two above areas. In addition, two other stations, named 


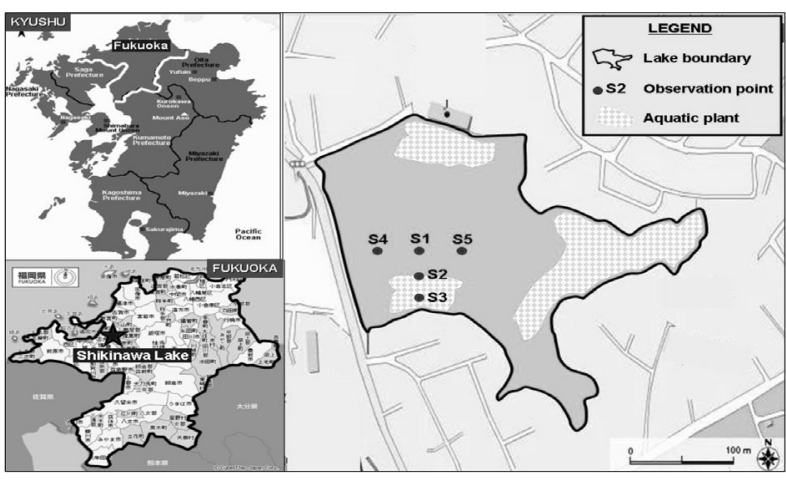

Fig. 1. Location of the Shikinawa Lake and observation points.

S4 and S5, were also used to investigate water quality inside lake water body at a shallow and a deep area, in comparison with water depths at other locations within the lake.

Water temperature, dissolved oxygen (DO), $\mathrm{pH}$, conductivity, turbidity, total dissolved solids, and some ions were measured directly inside the water body in the field at $0.5 \mathrm{~m}$ intervals to a depth of $2.5 \mathrm{~m}$. All of these data were observed in a period of 24 hours with time intervals of one-hour in daytime and two-hour during nighttime. The equipment used to measure these parameters was a portable multi-probe, called Horiba W-23XD (Horiba, Ltd., Kyoto - Japan).
For vertical water temperature measurement, five sensors systems were set at locations of observation points. Temperature was measured at $0.2 \mathrm{~m}$ intervals from water surface to bottom. Data were recorded automatically at every one minute in 24 hours using thermodacs recorders.

Water samples were collected from the field at the depths of $0.1 \mathrm{~m}, 1.5 \mathrm{~m}$ and $2.5 \mathrm{~m}$. These samples were analyzed for total nitrogen (T-N), ammonia, nitrite, nitrate, total phosphorus (T-P), and ortho-phosphorus using ion chromatography method. Equipment used for analyzing was SwAAt, a full-automatic wet chemical Auto-Analyzer developed by BL TEC K. K., Japan.

Hydraulic and meteorological data were also measured at the same time and locations of water quality measurements.

Because of errors occurred during measurement time and limitation of research in this step, this paper focused only on analyzing and discussing data obtained from three stations: S1, S2 and S3.

Data series of vertical water temperature at station S1 were unexpectedly stopped at 5:25 of the $8^{\text {th }}$ August due to recorder error. Generally, this series had similar trends in compared with data at other stations. Therefore, data series measured at station S1 were selected as a representative point of non-covered aquatic plant area.

Table 2. Japan Standard for some water quality parameters

\begin{tabular}{|c|c|c|c|c|c|}
\hline \multirow{2}{*}{ Class } & \multirow{2}{*}{ Water use } & \multicolumn{4}{|c|}{ Standard value } \\
\hline & & $p H$ & $C O D$ & $D O$ & Total coliform \\
\hline $\mathrm{AA}$ & $\begin{array}{l}\text { Water supply class } 1 \text {, } \\
\text { fishery class } 1 \text {, } \\
\text { conservation of natural environment, } \\
\text { and uses listed in A-C }\end{array}$ & $6.5-8.5$ & $\begin{array}{l}1 \mathrm{mg} / \mathrm{l} \\
\text { or less }\end{array}$ & $\begin{array}{l}7.5 \mathrm{mg} / \mathrm{l} \\
\text { or more }\end{array}$ & $\begin{array}{l}50 \mathrm{MPN} / 100 \mathrm{ml} \\
\text { or less }\end{array}$ \\
\hline $\mathrm{A}$ & $\begin{array}{l}\text { Water supply classes } 2 \text { and } 3 \text {, } \\
\text { fishery class } 2 \text {, } \\
\text { bathing, and uses listed in B-C }\end{array}$ & $6.5-8.5$ & $\begin{array}{l}3 \mathrm{mg} / \mathrm{l} \\
\text { or less }\end{array}$ & $\begin{array}{l}7.5 \mathrm{mg} / \mathrm{l} \\
\text { or more }\end{array}$ & $\begin{array}{c}1000 \\
\text { MPN/100 ml } \\
\text { or less }\end{array}$ \\
\hline B & $\begin{array}{l}\text { Fishery class } 3 \text {, } \\
\text { industrial water class } 1, \\
\text { agricultural water, } \\
\text { and uses listed in C }\end{array}$ & $6.5-8.5$ & $\begin{array}{l}5 \mathrm{mg} / \mathrm{l} \\
\text { or less }\end{array}$ & $\begin{array}{l}5 \mathrm{mg} / \mathrm{l} \\
\text { or more }\end{array}$ & - \\
\hline $\mathrm{C}$ & $\begin{array}{l}\text { Industrial water class } 2 \text { and } \\
\text { conservation of the environment }\end{array}$ & $6.5-8.5$ & $\begin{array}{l}8 \mathrm{mg} / \mathrm{l} \\
\text { or less }\end{array}$ & $\begin{array}{l}2 \mathrm{mg} / \mathrm{l} \\
\text { or more }\end{array}$ & - \\
\hline
\end{tabular}

(COD: Chemical Oxygen Demand. Source: Ministry of the Environment - Japan)

Table 3. Japan Standard for T-N and T-P

\begin{tabular}{|c|c|c|c|}
\hline \multirow{2}{*}{ Class } & \multirow{2}{*}{ Water use } & \multicolumn{2}{|c|}{ Standard value } \\
\hline & & $T-N$ & $T-P$ \\
\hline I & Conservation of natural environment and uses listed in $\mathbb{I}-\mathrm{V}$ & $\leq 0.1 \mathrm{mg} / \mathrm{l}$ & $\leq 0.005 \mathrm{mg} / \mathrm{l}$ \\
\hline II & $\begin{array}{l}\text { Water supply classes } 1,2 \text {, and } 3 \text { (except special types), } \\
\text { fishery class } 1 \text {, bathing, and uses listed in } \mathbb{I I}-\mathrm{V}\end{array}$ & $\leq 0.2 \mathrm{mg} / \mathrm{l}$ & $\leq 0.01 \mathrm{mg} / \mathrm{l}$ \\
\hline III & Water supply class 3 (special types) and uses listed in IV-V & $\leq 0.4 \mathrm{mg} / \mathrm{l}$ & $\leq 0.03 \mathrm{mg} / \mathrm{l}$ \\
\hline $\mathrm{IV}$ & Fishery class 2 and uses listed in $\mathrm{V}$ & $\leq 0.6 \mathrm{mg} / \mathrm{l}$ & $\leq 0.05 \mathrm{mg} / \mathrm{l}$ \\
\hline $\mathrm{V}$ & $\begin{array}{l}\text { Fishery class } 3 \text {, industrial water, agricultural water, and } \\
\text { conservation of the environment }\end{array}$ & $\leq 1 \mathrm{mg} / \mathrm{l}$ & $\leq 0.1 \mathrm{mg} / \mathrm{l}$ \\
\hline
\end{tabular}

(Source: Ministry of the Environment - Japan) 


\section{Japanese water quality standard}

Tables 2 and 3 show Japan Standard of some main water quality factors for different purposes.

\section{RESULTS AND DISCUSSIONS}

\section{Meteorological data}

Air temperature reached the peak $\left(35.7^{\circ} \mathrm{C}\right)$ at around $15: 15$, and lowest value $\left(23.8^{\circ} \mathrm{C}\right)$ found at early morning (see Fig. 2). Difference between the highest and lowest temperature was $11.9^{\circ} \mathrm{C}$ in value and about 11 hours in time. It reflected effects of solar radiation, which was high in daytime but very low during nighttime period. Highest solar radiation value, $0.93 \mathrm{~kW} / \mathrm{m}^{2}$, occurred around 12:00, approximately 3.5 hours earlier than the time when air temperature reached the maximum value. As usual, amounts of solar radiation were high at daytime, but sometime it dropped to very low level. Strangeness found here, air temperature started

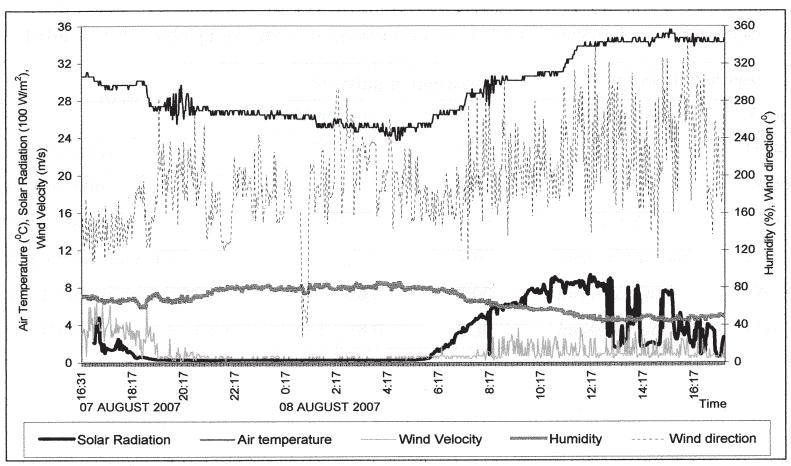

Fig. 2. Meteorological data.

to increase at about 1 hour earlier than solar radiation.

Winds, even light winds, can easily create rough conditions on the lakes. At the time of observation, wind action was strong at daytime, especially wind velocities increased up to about $6 \mathrm{~m} / \mathrm{s}$ at around 17:00 of the first day, with main direction was South-East. At the daytime of the second day, average wind velocity was $3 \mathrm{~m} / \mathrm{s}$, with directions varied from south of South-West to west of South-West. During nighttime, wind action was low in general direction of South.

Contrary to trends of wind action, solar radiation, and air temperature, relative humidity of the air was high in nighttime (around 80\%), about two times higher than daytime humidity.

\section{Water temperature}

Temperature is a measure of how cool or warm the water is, normally expressed in degree Celsius $\left({ }^{\circ} \mathrm{C}\right)$. Water temperature exerts a major influence on biological activity and growth. To a point, the higher the water temperature, the greater the biological activity. Temperature also governs types of organisms that can live in lake. Fish, zooplankton, phytoplankton, and other aquatic species all have a preferred temperature range. Temperature is also important because of its influence on water chemistry. The rate of chemical reactions generally increases at higher temperature, which in turn affects biological activity. An important example of the effects of temperature on water chemistry is its impact on oxygen. Warm water holds less oxygen than cool water, so it may be saturated with oxygen but still not contain enough for survival of aquatic life.

Daily cycle of water temperature

- Water temperature at station covered by aquatic plant (S3) tended to decrease later than other stations and about 4.5 hours later than the moment when solar radiation started to decrease. This time difference was not found when comparing data measured between S1 and S2 (see Table 4 and Fig. 3).

- Highest values of solar radiation were found at about 3.5 hours earlier than maximum values of water temperature. It meant that heat from solar and air needed time to heat up water in lake. In this case, time for water to reach the highest temperature was long, due to effect of strong wind.

- In estimation of the time when water temperature started to increase, this moment found firstly at station $\mathrm{S} 1$, which was about 1.5 hours later than solar radiation and 1 hour earlier than S2. At S3, water temperature started to increase later than at $\mathrm{S} 2$, with about 0.5 hour of time difference. These findings reflected effects of aquatic plant in delaying heat that came into water from solar radiation.

- Daily cycle of water temperature of different layers had the same tendency at varied time. This was a distinct property of a shallow lake, where heat took a very short time to come from surface to bottom of the lake.

- Larger fluctuation of water temperature occurred when the wind velocity was high. At the surface layer of stations S1 and S3, changes of temperature were vary large, especially at S3 sometime it was nearly equal to air temperature at the highest period. The reason here was

Table 4. Daily cyclic properties of water temperature and some meteorological parameters

\begin{tabular}{|c|c|c|c|c|}
\hline \multirow{2}{*}{ Item } & \multicolumn{2}{|c|}{ Starting to increase } & \multicolumn{2}{|c|}{ Starting to decrease } \\
\hline & Min Value & Time & Max Value & Time \\
\hline Air temperature $\left({ }^{\circ} \mathrm{C}\right)$ & 23.76 & 04:30 & 35.65 & $15: 30$ \\
\hline Solar Radiation $\left(100 \mathrm{Wh} / \mathrm{m}^{2}\right)$ & 0.0 & $5: 30$ & 0.90 & $13: 00$ \\
\hline Wind Velocity (m/s) & 0.46 & 02:00 & $>6.0$ & $17: 00$ \\
\hline Water temperature at $\mathrm{S} 1\left({ }^{\circ} \mathrm{C}\right)$ & $26.0-27.5$ & $7: 00$ & large variations & $17: 15$ \\
\hline Water temperature at $\mathrm{S} 2\left({ }^{\circ} \mathrm{C}\right)$ & $26.5-28.0$ & $8: 00$ & large variations & $17: 15$ \\
\hline Water temperature at $\mathrm{S} 3\left({ }^{\circ} \mathrm{C}\right)$ & $27.5-28.0$ & $8: 30$ & large variations & $17: 30$ \\
\hline
\end{tabular}




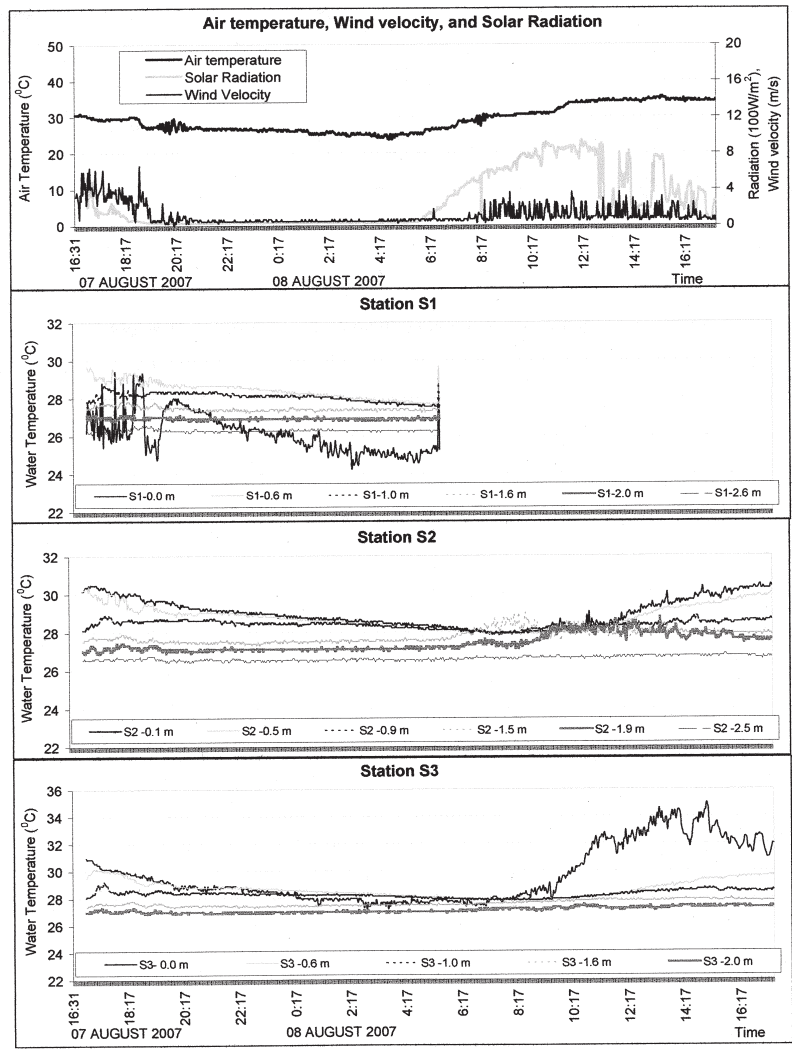

Fig. 3. Daily cyclic water temperature by layers at three stations and some meteorological parameters.

positions of the sensor, sometime it rose above water surface and recorded temperature was of the air. This situation did not happen at S2.

- The deeper water level, the smaller variation of water temperature at low values, and there were no significant temporal changes observed at the bottom layers of stations S2 and S3. Higher values of temperature of lower layers found at S3, while these values were lowest at $\mathrm{S} 1$.

\section{Vertical water temperature}

At water surface, effect of wind action was very high. As data shown in Fig. 4, trends of vertical water temperature at upper layers of station $\mathrm{S} 1$ and station S3 were inversed in comparison with each other, while it was not so much different at station S2.
- Stratification depths (thermoclines) started from $1.4 \mathrm{~m}$ to $1.6 \mathrm{~m}$ at station $\mathrm{S} 1$, from $1.3 \mathrm{~m}$ to $1.4 \mathrm{~m}$ at station $\mathrm{S} 2$, and from $1.2 \mathrm{~m}$ to $1.4 \mathrm{~m}$ at station $\mathrm{S} 3$. It meant that aquatic plant cover played a very important role in stratification of vertical water temperature. In the station where there was no cover, heat from solar radiation penetrated deeply into the water body.

- Temperature tended to decrease by water depths, the large variation was found at shallower water layers, while at deeper layers, variation of temperature was very small at all time. This phenomenon was caused by effects of solar radiation.

- In comparisons of temperature measured at three stations, there was very small difference at water surface layers. But at the bottom of the lake, highest values found at station S3, and it was smaller at S2 and lowest at S1.

- At station S1, water temperature at the lake surface was smaller than that in some next below layers, this difference did not find at S2, while it was inversed at S3. This phenomenon caused by impacts of wind actions and aquatic plant cover.

\section{Dissolved oxygen}

Oxygen is produced during photosynthesis and consumed during respiration and decomposition. Because it requires light, photosynthesis occurs only during daylight hours. Respiration and decomposition, on the other hand, occur 24 hours a day. This difference alone can account for large daily variations in DO concentrations. During the night, when photosynthesis cannot counterbalance the loss of oxygen through respiration and decomposition, DO concentration may steadily decline. It is lowest just before dawn, when photosynthesis resumes.

Other sources of oxygen include the air and inflowing streams. Oxygen concentrations are much higher in air, which is about $21 \%$ oxygen, than in water, which is a tiny fraction of $1 \%$ oxygen. More oxygen dissolves into water when wind stirs the water; as the waves create more surface area, more diffusion can occur.

Another physical process that affects DO concentrations is the relationship between water temperature and gas saturation. Cold water can hold more of any gas, in
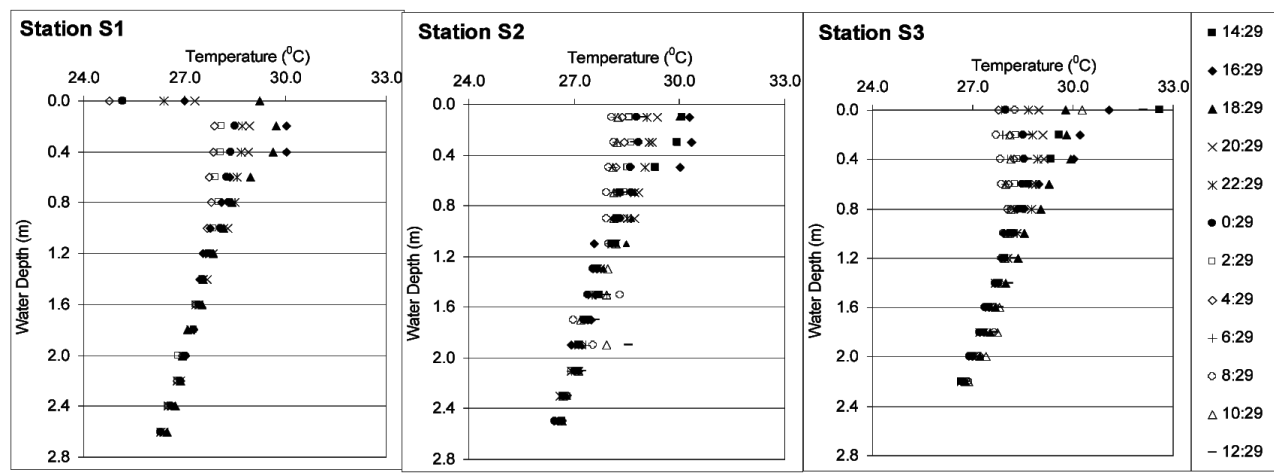

Fig. 4. Time variation of vertical temperature measured at three stations. 
this case oxygen, than warmer water. Warmer water becomes "saturated" more easily with oxygen. As water becomes warmer it can hold less and less DO. So, during the summer months in the warmer top portion of a lake, the total amount of present oxygen may be limited by temperature.

Daily cycle of DO

- This lake had high concentration of DO (see Fig. 5), especially at layers that shallower than $1.6 \mathrm{~m}$ from water surfaceAll measured DO concentrations were satisfied Japanese standard of water quality used for agri-

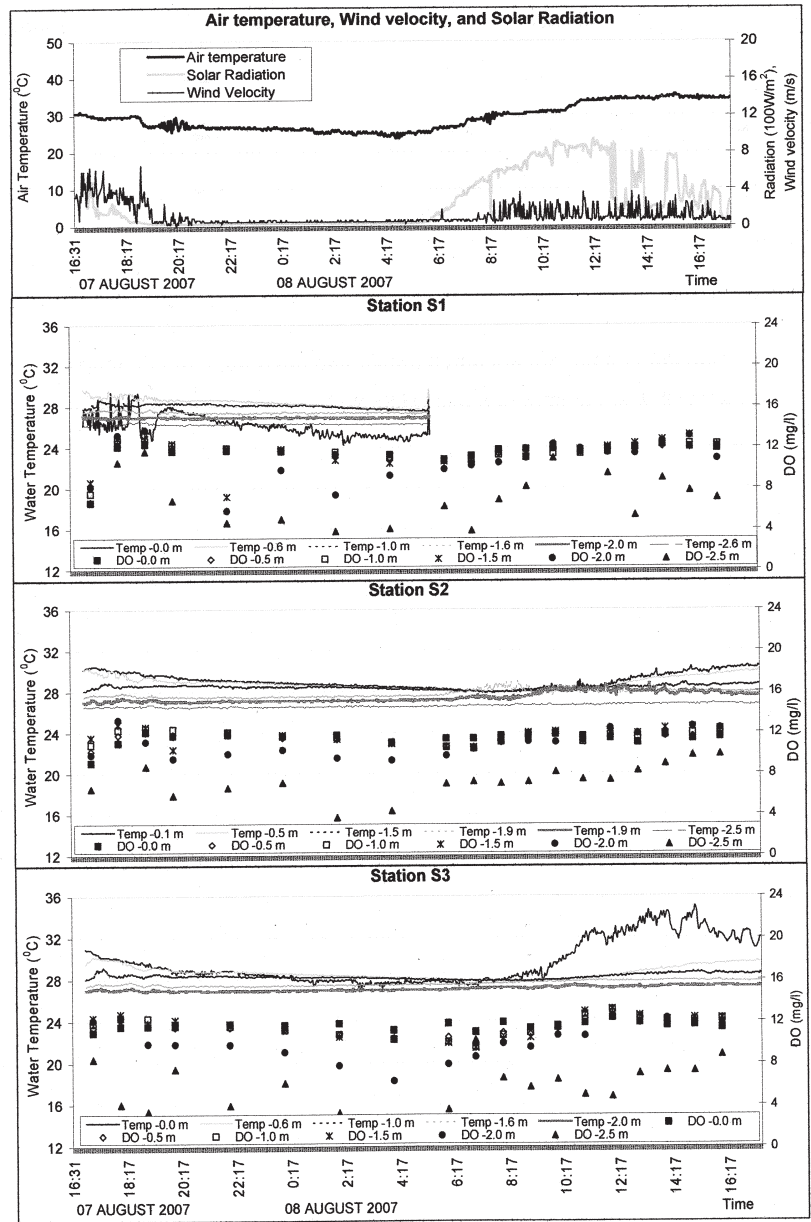

Fig. 5. Daily cyclic DO, temperature by depths at three stations and some meteorological parameters. culture and natural environmental conservation.

- DO concentration of shallow water layers (shallower than $1.5 \mathrm{~m}$ from water surface) at all of three stations had the same tendency of a daily cycle with water temperature. This phenomenon might be caused by photosynthesis of aquatic plant.

- The average transparency level of water in the lake was measured around $1.6 \mathrm{~m}$. Therefore, in layers deeper this depth, photosynthesis of aquatic plan was weak and, conversely, respiration activity was high. These caused low values of DO found at deeper layers of all three stations

- Shallow layers hold high DO concentration at the time period when wind action was strong, because of high amount of DO came from the air. On the contrary, DO concentrations at deeper layers were low and unstable.

- In daytime, DO found at station S1 was generally higher than stations S2 and S3, and it was inversed in nighttime. This phenomenon was similar to the general trend of water temperature variation, caused by high solar radiation and strong wind action occurred at daytime and daily convection cycle of the water inside the lake.

- At the time when wind velocities were high, differences were small among DO concentration of all water layers. When wind action was weak, conversely, these differences were high. This phenomenon demonstrated that the lake was well-mixed under strong period of wind action.

Vertical variation of $D O$

- Because the lake was shallow and easily mixed by wind, the DO concentration (see Fig. 6) was fairly consistent throughout the water column at the time when wind action was strong. When it was calm, some pronounced declines with depth were observed.

- All of DO variations in vertical direction had inverse tendencies in comparison with trends of vertical water temperature. This data showed that activity of aquatic plan, algae... inside the water was increasing with water depth until around $2.0 \mathrm{~m}$; even average transparency level measured was only about $1.6 \mathrm{~m}$.

- On the other hand, upper layers normally containing more DO than lower layers, but the trends in all

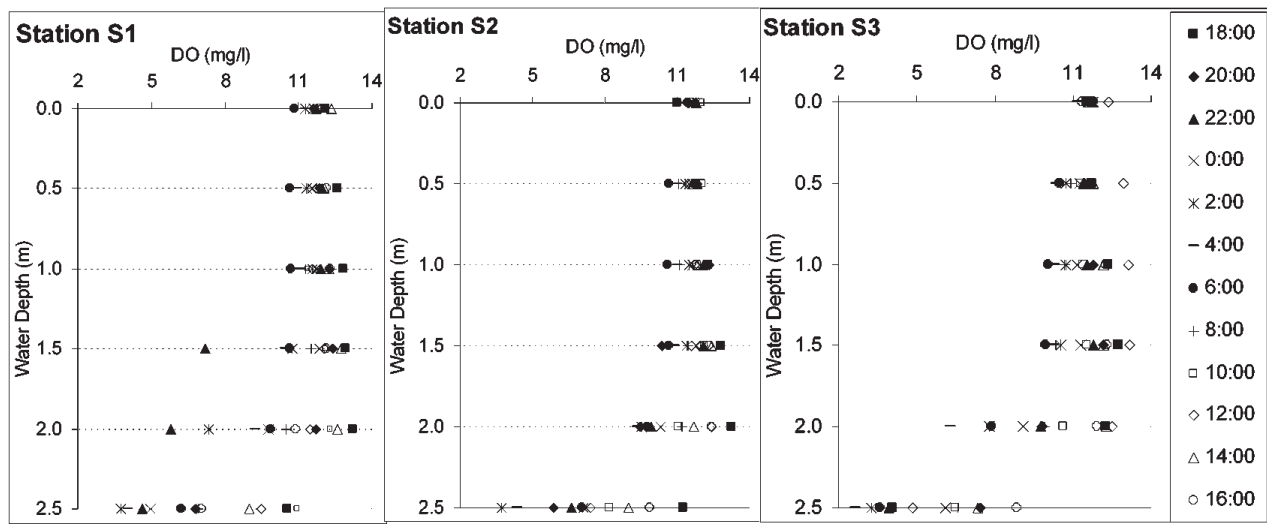

Fig. 6. Time variation of vertical DO concentration measured at three stations. 
three stations were inversed. This occurrence showed that at high water temperature, dissolving ability of oxygen was limited. Another reason was convection of water layer caused by wind action.

- DO concentration dropped to very low values at the lake bottom because oxygen consumption was greatest near the bottom of a lake, where sunken organic matter accumulated and decomposed.

\section{Conductivity}

Conductivity is the ability of the water to conduct an electrical current, and is an indirect measure of the ion concentration. The more ions present, the more electricity can be conducted by the water. This measurement is expressed in microsiemens per centimeter $(\mu \mathrm{S} /$ $\mathrm{cm})$ or milisiemens per meter $(\mathrm{mS} / \mathrm{m})$. Conductivity is temperature sensitive and increases with increasing temperature.

Daily cycle of conductivity

- Daily cycle profile of conductivity reflected the temperature sensitive property of conductivity of water in lake. These trends were found at all of water layers of

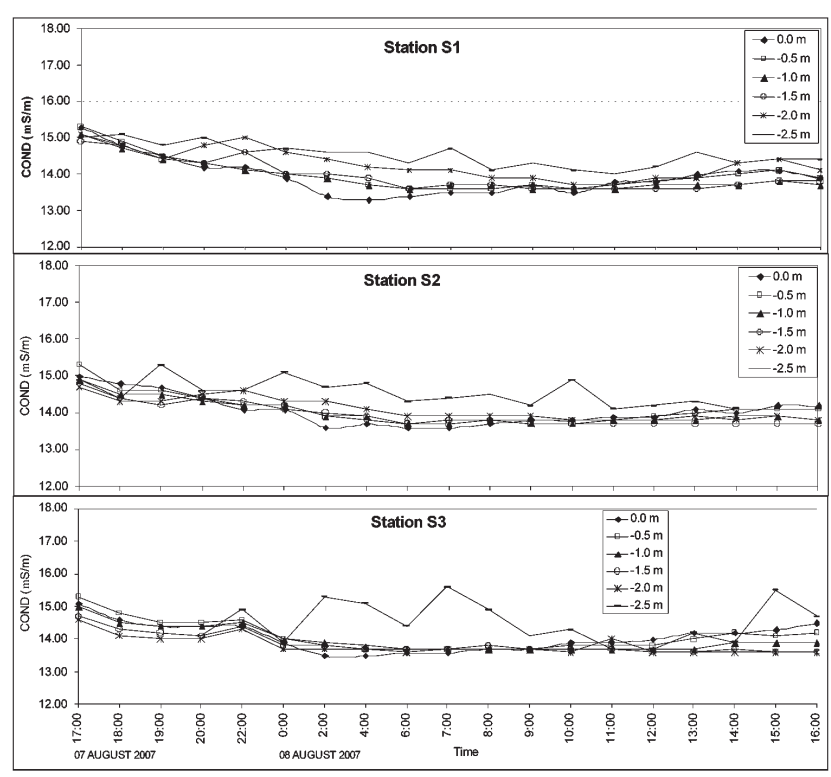

Fig. 7. Daily cycle of conductivity measured at three stations. all three stations (see Fig. 7).

- At station S1, where water surface was not covered by aquatic plants and vertical changes of water temperature were large, differences of conductivity of water layers were big at daytime and small at nighttime. Conversely, as presented by data obtained at stations S2 and S3, where vertical water temperatures were more stable, differences of conductivity of water layers during the daytime were bigger than that at the nighttime.

- Generally, bottom layers had high values of conductivity, but they were not steady. The highest values of conductivity found at all three stations were not big difference (from 15.3 to $15.5 \mathrm{mS} / \mathrm{m}$ ), but this value of data measured at S1 was found at the first layer, for S2 was the second layer, while it was measured the bottom layer at S3.

- The lowest conductivity, $13.25 \mathrm{mS} / \mathrm{m}$, was measured in the surface layer of station $\mathrm{S} 1$ at 4:00 of the second day, when water temperature was dropped to lowest values. This value was $13.6 \mathrm{mS} / \mathrm{m}$ at $\mathrm{S} 2$ and $13.5 \mathrm{mS} / \mathrm{m}$ at S3, observed at the time which was about 2 hours earlier than $\mathrm{S} 1$.

Vertical variation of conductivity

- As shown in Figs. 7 and 8, conductivity of the bottom layers tended to increase with water depth. This was inversely proportional to vertical water temperature changes and did not follow general temperature sensitive property of conductivity.

- Another important property of conductivity variation affected by aquatic plant cover was found here. At station S1, largest time difference of conductivity was observed at surface layer, while it was found at the bottom layer of S3. At station S2, time variations were similar at all water layers from surface to bottom of the lake.

- From above investigations, it could be found that, beside effects of ion concentration in waste water drained into the lake, aquatic plant cover had significant impacts to variations of conductivity of the lake water.

\section{Nutrient}

Nutrients are chemical elements and compounds found in the environment that plants and animals need to grow and live. For water-quality investigations, the various forms of nitrogen and phosphorus are the nutri-

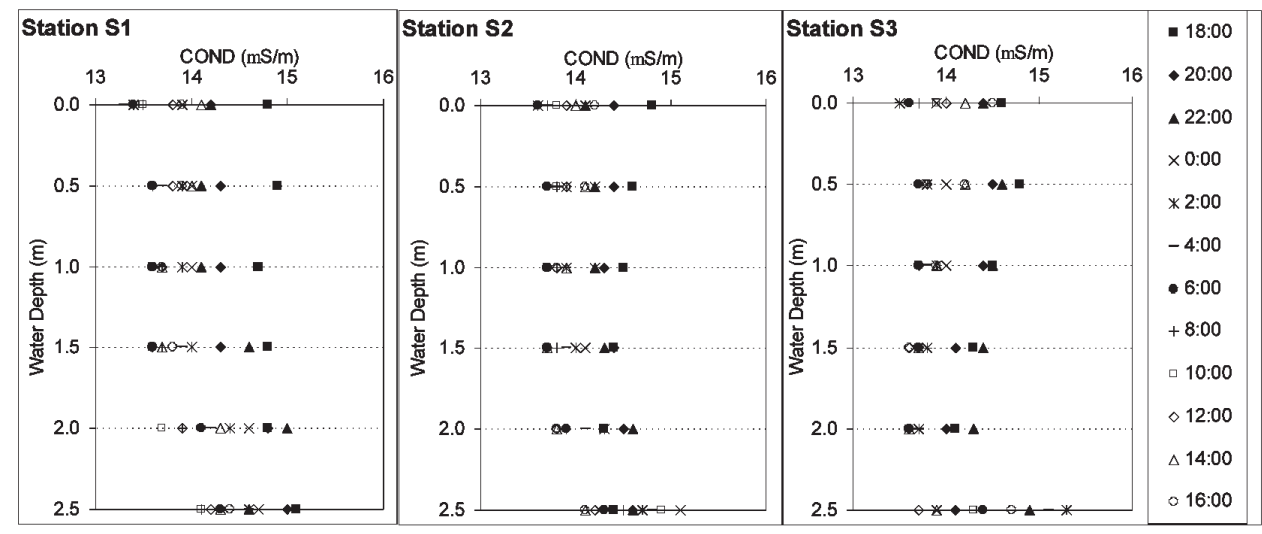

Fig. 8. Time variation of vertical conductivity measured at three stations. 
ents of interest. The forms include nitrate, nitrite, ammonia, organic nitrogen (in the form of plant material or other organic compounds) and phosphates (orthophosphate and others). Nitrate is the most common form of nitrogen and phosphates are the most common forms of phosphorus found in natural waters. High concentrations of nutrients in water bodies can potentially cause eutrophication and hypoxia.

Nitrogen and phosphorus are common components of fertilizers, animal and human wastes, vegetation, aquaculture and some industrial processes. Nutrients in surface water come from both point and non-point sources including agricultural and urban runoff, wastewater treatment plants, forestry activities and atmospheric deposition. Nutrients in non-point source runoff come mostly from fertilizer and animal wastes. Nutrients in point source discharges typically come from human waste, food residues, cleaning agents and industrial processes.

\section{Daily cycles of nutrients}

Nitrogen components

In water body, nitrogen exists in three main types including organic matters, ammoniac, and oxidation nitrite $\left(\mathrm{NO}_{2}^{-}\right)$, nitrate $\left(\mathrm{NO}_{3}^{-}\right)$. They are main nutrients in the water and, therefore, are very important for water environment.

Ammoniac $\mathrm{NH}_{3}$ has two main components including $\mathrm{NH}_{3}$ and $\mathrm{NH}_{4}^{+}$and depends on $\mathrm{pH}$ of water. If $\mathrm{pH}$ low,

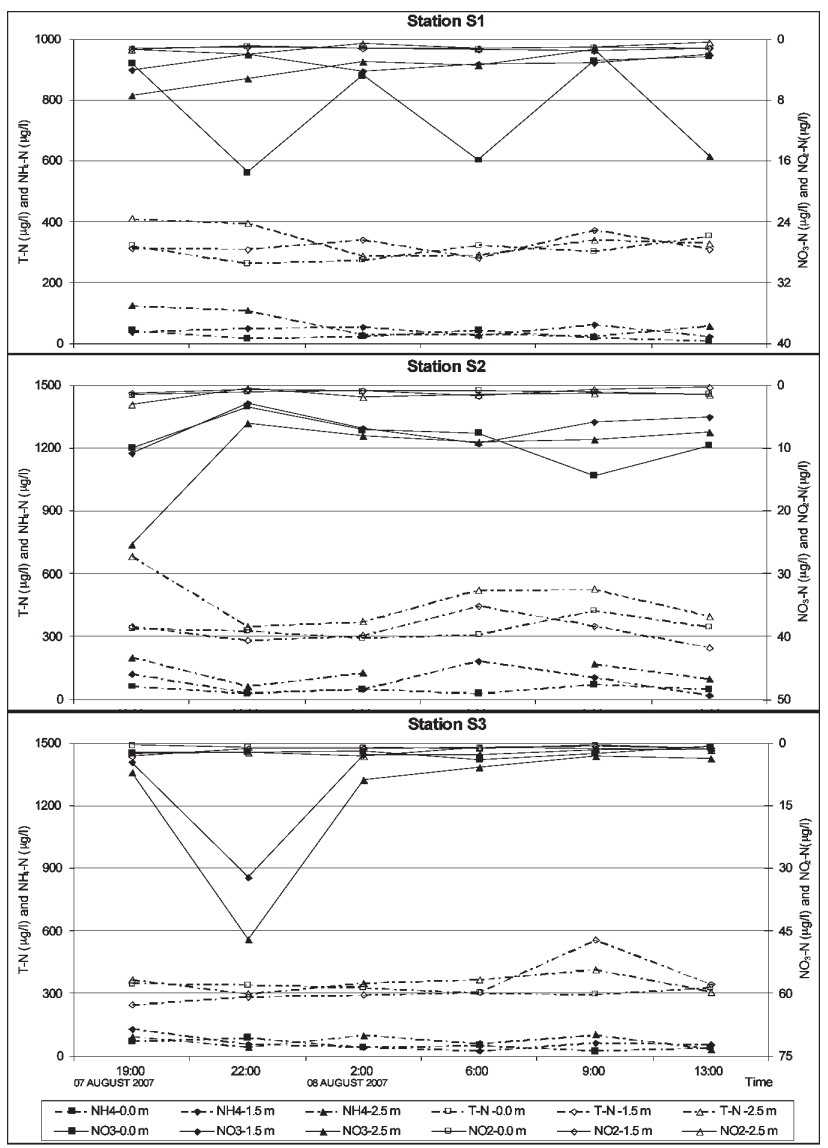

Fig. 9. Daily cycle of nitrogen components measured at three stations. ammoniac tends to hold higher concentration of ion $\mathrm{NH}_{4}{ }^{+}$ and, on a contrary, this ion is high at high $\mathrm{pH}$ environment. In relationship to water temperature, concentration of $\mathrm{NH}_{4}^{+}$is low at high temperature. If concentration of ammonia is high, at high temperature, water tends to contain high concentration of $\mathrm{NO}_{2}^{-}$.

As results shown in Fig. 9, there were no significant tendencies in daily cycle of almost nitrogen components.

Values of $\mathrm{NH}_{4}^{+}$were a little high but they still satisfied the water quality standard for domestic uses of The European Union (EU), less than $0.5 \mathrm{mg} / \mathrm{l}$, and World Health Organization (WHO), less than $1.5 \mathrm{mg} / \mathrm{l}$. Varied tendency of $\mathrm{NH}_{4}{ }^{+}$also depends on $\mathrm{pH}$ and temperature of the lake water. Other nitrogen components, e.g., nitrite ion $\mathrm{NO}_{2}^{-}$, and nitrate ion $\mathrm{NO}_{3}{ }^{-}$were low and all of data analyzed were lower than water quality criteria for agricultural uses of $\mathrm{EU}$ (50 mg $\left.\mathrm{NO}_{3}^{-} / 1,0.1 \mathrm{mg} \mathrm{NO}_{2}^{-} / 1\right)$, WHO (50 mg $\mathrm{NO}_{3}^{-} / 1,3 \mathrm{mg} \mathrm{NO}_{2}^{-} /$), and America (45 mg $\left.\mathrm{NO}_{3}^{-} / \mathrm{l}, 3.3 \mathrm{mg} \mathrm{NO}_{2}^{-} / \mathrm{l}\right)$. All concentrations of $\mathrm{T}-\mathrm{N}$ were satisfied Japan water quality criteria for agriculture and fishery (1 mg/l or less).

When evaluating impacts of aquatic plant cover on variations of nitrogen components, some notable results were defined. Concentration of ion $\mathrm{NO}_{3}^{-}$measured at station S1 was much higher than concentration of ion $\mathrm{NO}_{2}^{-}$, this distinction was smaller at station $\mathrm{S} 2$ and very small at station S3. Values of T-N and $\mathrm{NH}_{4}{ }^{+}$had biggest daily variation at the bottom of station $\mathrm{S} 1$, and it occurred at some deep layers of $\mathrm{S} 2$, but no big changes was found at S3. These trends were conversed when comparing obtained values of ion $\mathrm{NO}_{3}{ }^{-}$. Changes of $\mathrm{NO}_{2}{ }^{-}$ concentrations during observed daily cycle were very small.

\section{Phosphorus components}

The quantity of phosphorus present in the water column is especially important since phosphorus is the nutrient that most often controls aquatic plant growth and the rate at which a lake ages and becomes more eutrophic. In the presence of oxygen, lake sediments act as a phosphorus trap, retaining phosphorus and, thus, making it unavailable for aquatic plant growth. However, if bottom-water oxygen is depleted, phosphorus will be released from the sediments and may be available to promote aquatic plant growth. In some lakes, the release of phosphorus from the bottom sediments is the primary source of phosphorus loading (or input). By reducing amount of phosphorus in a lake, it may be possible to control the amount of aquatic plant growth. In general, lakes with a phosphorus concentration greater than $20 \mu \mathrm{g} / \mathrm{L}$ (micrograms per liter, or parts per billion) are able to support abundant plant growth and are classified as nutrient-enriched or eutrophic.

- Similar to nitrogen components, the daily cyclic variations of concentration of $\mathrm{T}-\mathrm{P}$ and ion $\mathrm{PO}_{4}^{-}$had no clear trends (see Fig. 10).

- All values of T-P measured at all three stations $\mathrm{S} 1$, $\mathrm{S} 2$ and $\mathrm{S} 3$ were lower than limitation $(0.1 \mathrm{mg} / \mathrm{l})$ which regulated by Japanese water quality standard for uses of agricultural and water environmental conservation. 


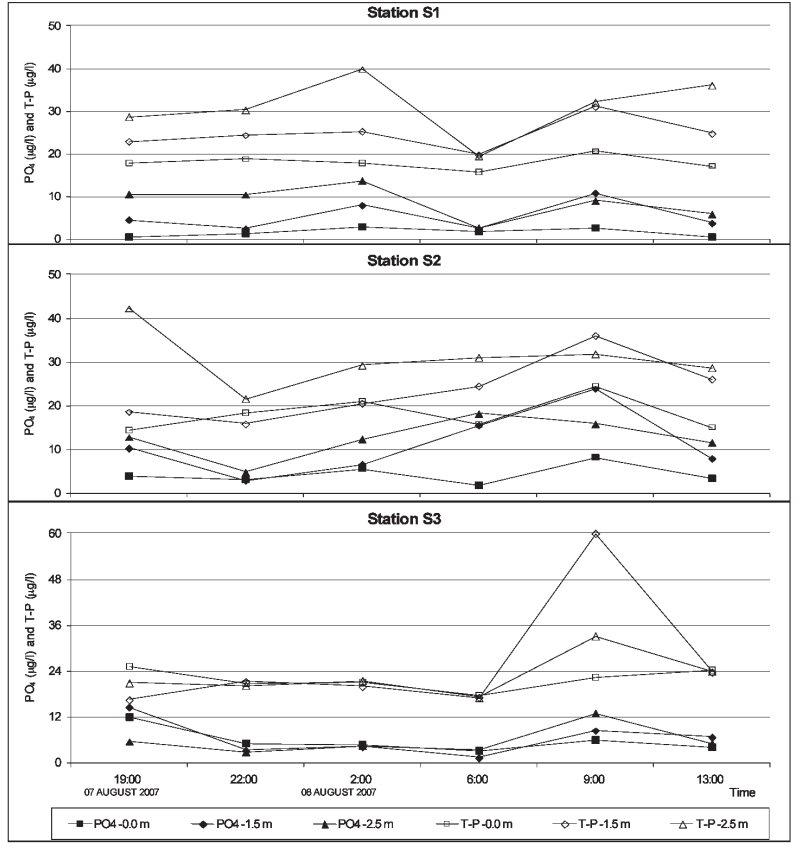

Fig. 10. Daily cycle of phosphorus components measured at three stations.

- Although analyzed at low values, variations of T-P were large in both of temporal variation and layers difference at station $\mathrm{S} 1$, while it was smaller variation at S2 and more steady at S3 (except separated values analyzed from sample collected at 9:00 of the second day).

- Almost values of $\mathrm{PO}_{4}^{-}$were smaller than $10 \mu \mathrm{g} / \mathrm{l}$. The smallest amount and most stable variation of this parameter were observed at station S3, while they were higher and unstable when measured at two stations S1 and S2. The lower water depth, the higher amounts of $\mathrm{PO}_{4}^{-}$were found, as a result of oxygen depletion at bottom layers.

\section{Limiting nutrient}

In eutrophication management it is often important to identify which of the several nutrients used for plant nutrition ultimately controls the level of plants in the water body. A first cut at identifying this "limiting nutrient" is to compare the levels of the nutrients in the water with the cell stoichiometry. This is most commonly done for nitrogen and phosphorus. A rough rule of thumb for assessing which nutrient in the water is limiting relates to the nitrogen-to-phosphorus ratio. This ratio in bio-

Table 5. N:P ratios measured in the Shikinawa Lake

\begin{tabular}{rrrrr}
\hline \multirow{2}{*}{ Time } & \multirow{2}{*}{$\begin{array}{c}\text { Depth } \\
(\mathrm{m})\end{array}$} & \multicolumn{3}{c}{ TN/TP Ratio } \\
\cline { 3 - 5 } & & 13.71 & 18.79 & 14.98 \\
\hline 19:00 & 1.5 & 14.36 & 16.18 & 17.50 \\
$19: 00$ & 2.5 & 13.58 & 14.89 & 14.73 \\
$2: 00$ & 1.5 & 7.22 & 12.71 & 16.38 \\
$2: 00$ & 2.5 & 14.19 & 18.31 & 18.01 \\
$6: 00$ & 1.5 & 15.02 & 16.95 & 21.47 \\
$6: 00$ & 2.5 & 12.04 & 9.79 & 9.31 \\
$9: 00$ & 1.5 & 10.64 & 16.58 & 12.56 \\
$9: 00$ & 2.5 & 12.57 & 9.54 & 14.56 \\
$13: 00$ & 1.5 & 9.18 & 13.92 & 12.99 \\
$13: 00$ & 2.5 & & & \\
\hline
\end{tabular}

mass is approximately 7.2 (Charpa S. C., 1998), therefore, N:P ratios less than 7.2 suggest that nitrogen is limited and, conversely, higher levels imply that phosphorus will limit plant growth.

As the analyzed data shown in Table 5, at all of observation points in the Shikinawa Lake, ratios N:P were higher than 7.2 , that proved phosphorus limiting situation in this lake.

\section{Determining trophic status of the lake}

Lakes are commonly classified as oligotrophic, mesotrophic, or eutrophic. Oligotrophic lakes are generally deep and clear with little aquatic plant growth. These lakes maintain sufficient DO in the cool, deep bottom waters during late summer to support cold water fishes. By contrast, eutrophic lakes are generally shallow, turbid, and support abundant aquatic plant growth. In deep eutrophic lakes, the cool bottom water usually contains little or no DO. Therefore, these lakes can only support warm water fish such as bass and pike. Mesotrophic lakes are lakes with an intermediate level of productivity, greater than oligotrophic lakes, but less than eutrophic lakes. These lakes are commonly clear water lakes with beds of submerged aquatic plants and medium levels of nutrients.

A method has been devised for "rating" lakes. This method is called the trophic state index (TSI) or the Carlson index (after the scientist who devised it). A lake which has TSI less than 40 can be classified as an oligotrophic lake, if TSI is greater than 60 , it is called a eutrophic lake, and mesotrophic status is defined with TSI ranged from 40 to 60 .

TSI can be calculated by using the Secchi disk depth (a method to measure transparency level of water in lakes), the T-P concentration at the surface of the lake, or the chlorophyll a concentration at the surface. Either one day's values or, preferably, average values over the summer can be used.

In this paper, measured average transparency level of the lake (about $1.6 \mathrm{~m}$ ) and values of T-P analyzed from collected water samples were used to calculate TSI as following equations:

Using Secchi disk depth: TSI=60-14.41 (In SD)=60-

$14.41(\ln 16.0)=53.2$

Using total phosphorus: TSI=14.42 (In T-P) + 4.15

where SD is the Secchi depth in meters, T-P is the total phosphorus concentration measured in the surface water in $\mu \mathrm{g} / \mathrm{l}$, and $\ln$ stands for the natural log of a

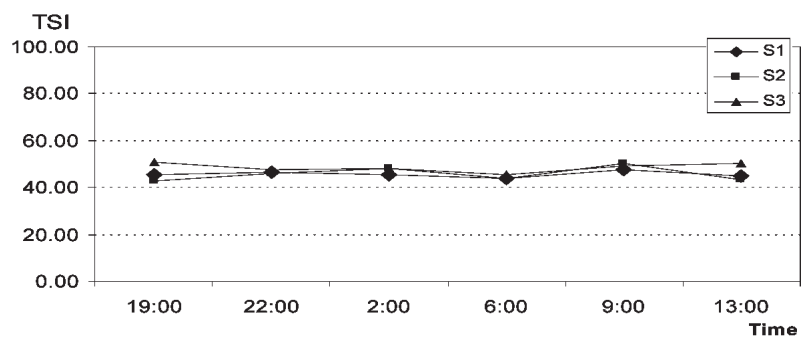

Fig. 11. TSI index calculated at three stations using surface concentration of T-P. 
number.

Based on results of TSI calculated from transparency level of the water and amount of T-P analyzed (see Fig. 11), the Shikinawa Lake could be classified as a mesotrophic lake.

\section{CONCLUSIONS}

Based data observed in the Shikinawa Lake, some main properties of daily cycle and vertical distribution of the lake water quality parameters, effects of meteorological condition and aquatic plant cover on their situation, and trophic status of the lake, were found out as follows:

1. All of water parameters measured at the Shikinawa Lake were satisfied water quality standards of Japan for agricultural supply and water environmental conservation. However, some strange points found at increasable ion concentration and high value of ammonia might be caused by contaminations came from drainage water which flowed into the lake.

2. Most of water quality parameters had a clear variation tendency in a daily cycle. But in vertical distribution, it was difficult to define general trends of some nutrient components.

3. Meteorological factors, especially wind action and heat flux from solar radiation had significant effects on amount and distribution of water quality in the lake.

4. Aquatic plant cover played an important role in variations of lake's water quality indicators, in both of hori- zontal and vertical directions.

5. When evaluating eutrophication using $\mathrm{N}$ : $\mathrm{P}$ ratio, phosphorus limiting situation was found in this lake, it meant that after a limited time, phosphorus ran out, algae could no longer grow and excess nitrogen remained in the water.

Finally, from observed and analyzed results, it can be concluded that the Shikinawa Lake was a small, shallow, mesotrophic, and phosphorus limited lake at the time of observation.

\section{REFERENCES}

Cat, L. V. Chemical bases and Water treatment technology (in Vietnamese). Hanoi National Natural Sciences and Technology, 1999

Charpa, S. C. Surface water quality modeling. McGraw-Hill, 1998

Hoeven, J. and T. Dwelle Lake water quality assessment for the Jamestown Reservoir. North Dakota Department of Health, 2005

Lap BQ, and Mori K, A two-dimensional numerical model of wind-induced flow and water quality in closed water bodies. Paddy and Water Environ (2007) 5: 29-40

Martin, J. L and S. C. McCutcheon Hydrodynamic and Transport for Water Quality modeling. Lewis Publisher, 1998

Ministry of the Environment of Japan (MOE) Environmental quality standard for water pollution. in http://www.evn. go.jp/en/water/wq/wq.html

Ozaki, A, Mori K., Inoue E., and Haraguchi T., Impact of aquatic plants on entrainment phenomena based on wind-induced flow in a closed density. Paddy and Water Environ (2004) 2: 125-134 